\title{
RESEARCH METHODS AND TECHNIQUES APPLIED DURING PREPARATION OF REGIONAL INNOVATION STRATEGIES OF POLISH REGIONS
}

\author{
Dariusz WYRWA \\ Rzeszow University of Technology, The Faculty of Management; dwyrwa@prz.edu.pl, \\ ORCID: 0000-0003-1327-795X
}

Purpose: Review of regional innovation strategies of Polish regions to assess the scope of research methods and techniques applied during their preparation.

Design/methodology/approach: Analysis of regional innovation strategies applicable in all voivodeships with respect to the research methods and techniques used during their preparation. Findings: Polish regions apply diversified methods and techniques that allow them to determine the directions of innovation development, yet in the course of smart strategy identification they encountered limitations with respect to the availability of quantitative aggregated data on the voivodeship or lower levels; therefore, some of them reached to surveys and interviews, as well as the Delphi method which allowed for mitigating the impact of these deficiencies. The regions did not focus exclusively on fulfilling the ex ante condition, but they were intent on proper designation of the priority areas with respect to the aid, which is testified by, among others, reaching to results of foresight type projects and up-dates of the prepared strategies.

Originality/value: A comprehensive review of regional innovation strategies applicable in the Polish regions until 2020 and a concise analysis of methods and techniques applied during their preparation as a starting point for the improvement of processes of preparation of subsequent innovation strategies in voivodeships.

Keywords: regional innovation strategy, smart specialisation.

Category of the paper: research paper.

\section{Introduction}

The first Polish regional innovation strategies (RIS) were prepared as part of the 5th Framework Programme of the European Union thanks to the RIS-NAC (Regional Innovation Strategy Projects in Newly Associated Countries) projects. Five voivodeships (Opolskie, Śląskie, Warmińsko-Mazurskie, Wielkopolskie and Zachodniopomorskie) started to work on them in 2002. Subsequent financial strategies were financed by the Ministry of Science 
and Digitisation and the 6th Framework Programme of the European Union, thanks to which in 2005, 15 out of 16 Polish voivodeships implemented regional innovation strategies (Matusiak, 2005). The last region to adopt the strategy in 2008 was the Mazowieckie voivodeship.

The European Union regions implement regional innovation strategies due to the fact that they may foster innovation of regions, and in consequence their competitiveness, which is essential in the context of functioning in a globalised economy. Development of the concept of smart specialisation requires designation of priority areas as part of which aid is concentrated. Their identification calls for selection and application of proper research methods and techniques.

\section{Innovation Policy of the European Union in Global Economy}

The formation of international economy is greatly impacted by globalisation processes, which started to intensely develop in the second half of the 20th century, and in Europe in particular in the 1980s and 1990s, which may have been affected by the socio-economic transformation in the Central and Eastern Europe (Herodowicz, 2018).

According to A. Stabryła, globalisation in general means "significant and complex processes which take place on a global scale, which constitute a higher, more advanced and complex stage of the process of internationalisation of economic operation and which exert a fundamental impact on the present and future growth of international economy, its directions and nature" (Stabryła, 2009). Some authors define it by taking into account the perspective of its effects as increased flow of goods, services, capital, people and information across borders (Jacoby, and Meunier, 2010). According to G.W. Kołodko, it is related to the liberalisation and the progressing integration of markets operating in a certain separation into a single international market (Kołodko, 2007). As a result of it, national markets are losing their significance, as they are becoming more linked by the exchange of goods and services, along with the flows of capital and technology. Globalisation is a process that encompasses various areas, but usually its economic dimension becomes the basic object of dialogue. It is characterised by increased exchange of products and growth of inter-dependence of national economies (Surugiu, Surugiou, 2015).

Globalisation in the economic approach is perceived as a beneficial process. Elimination of barriers and development of the global market is conducive to the popularisation of modern production technologies and introduction of innovations. Increased competitiveness and international investments activate economies, whereas the developing cooperation integrates people from different cultures. Elimination of barriers is conducive to the free movement of people and goods, which takes place in ever-shortening time (Grzybowska, 2013). Nevertheless, one cannot overlook the dangers that it poses for national economies. As a result 
of globalisation, the global economy is divided into the centre, which comprises well-developed economies with the largest trans-national economies, and the periphery, which is often the outlet market for the products manufactured on the basis of technologies created by entities that make up the centre. Faced with global competition, numerous domestic enterprises turn out to be too weak to export their products and services. Highly qualified employees often emigrate from the peripheral areas in order to find better conditions for pursuing their professional career in the centre (Brożyk, 2006).

Since the onset of intensified globalisation processes, the European Union has been taking action to become a part of them and to accomplish the best possible results in the economic sphere. Benefits which the community derives from it are highlighted. It is estimated that the European Union's share in the global export exceeds $15 \%$, out of which over $80 \%$ is the production of small and medium-sized enterprises. Additionally, in 2017 export outside of the EU supported approx. 35 million jobs in the Union (Facts...). The European Union is striving to maximise benefits resulting from globalisation, simultaneously alleviating its negative effects. Integration as such was already the basis. To this aim, various steps are taken which would allow for the management of globalisation. One of them is creation of new policies and instruments which could allow for using the opportunities which are offered by the global market (Jacoby, and Meunier, 2010). An example may be provided by the continually pursued innovation policy, which is aimed at ensuring growth of competitiveness of the EU economy on the international arena, given the fact that it is essential in the competition with other economies, in particular the USA and Japan.

\section{Regional Innovation Strategies in the European Union}

Issues related to the innovation development process are the object of studies the purpose of which is analysis of its determinants (Conway, and Steward, 2009). For years, politicians and scientists around the world have been focusing on building innovation systems in a mode that allows for proper use of knowledge and learning (Lundvall, 2007). They are meant to reinforce the economy and to increase its competitiveness. Competitiveness of enterprises and economies does not, however, have to be tantamount to their innovation, as there may be other modes of improving it than via development of innovation (de Jong, 2011). Innovation and competitiveness are under the impact of various factors (Siqueira, and Cosh, 2008); nevertheless, the justifiability of creating innovation strategies which could adequately stimulate development of individual entities and entire economies is not questioned (Clark, and Guy, 1998; Bowonder, Dambal et. al., 2010; Weresa, 2012; Moen, Tvedten et al., 2018). However, it should be noted that this requires building of innovation capacity (Nogalski, and Karpacz, 2012). 
Nevertheless, the European Union is characterised by significant diversity in the level of economic development, not only on the level of member states, but also regions. Therefore, the innovation policy is also implemented on the regional level, and its instruments are regional innovation strategies. The first projects aimed at their preparation were launched in Europe between 1993 and 1994 and bore fruit in the drawing up of documents known as the regional technological plans, in order to reach the number of approx. 150 implemented strategies in the regions in the course of the next 15 years (Third report..., 2004).

In 2013, the obligation of preparation of regional innovation strategies by the EU regions was introduced, which constitutes the ex ante condition that allows for the use of the funds of the European Regional Development Fund (ERDF). In line with the regulation, during preparation of a strategy, a SWOT analysis or a similar method is to be applied in order to focus the resources on the limited set of priorities of research and innovations (Regulation..., 2013). An additional requirement allowing for such concentration was inclusion of the so-called smart specialisations (Foray, 2009). Earlier, the created innovation strategies traditionally focused on horizontal activities and policies aimed at improvement of general conditions and possibilities of innovation development, such as the R\&D infrastructure, human capital, reinforcement of scientific centres. Apart from horizontal actions, the new approach to the formation of the innovation policy in the regions based on smart specialisations makes the regions liable for taking into account a more vertical (and previously quite not-neutral) intervention logic, in the formation of which the process of identification and selection of its desired areas was important (based on technology, areas and sub-systems which should be treated as priorities as part of a regional policy) (Foray, and Goenega, 2013). The analysis of the first regional innovation strategies prepared in the European Union showed the limitations and weaknesses in the process of their preparation (Capello, and Kroll, 2016). It was necessary to apply a new approach to identify the priority areas. Initially, the concept of a smart specialisation was not well described and did not have a proper theoretical background, in particular with respect to methodology and methodics; therefore, regions started to individually work out the methods of their selection. Three different approaches were used, i.e. relying on quantitative, qualitative and mixed methods. The procedural nature of the concept of smart specialisation requires application of qualitative analyses; however, these methods are considered less rigorous or offering less objective results for the formation of an innovative policy than quantitative methods. In relation to this, development of the mixed approach is recommended (Fellnhofer, 2017; Griniece, and Panori, 2017). 


\section{Use of Research Methods and Techniques in the Process of Preparation of Regional Innovation Strategies in Poland}

In the study whose aim was the identification of research methods and techniques used for the preparation of regional innovation strategies, the desk research method was used. Current strategies and regional strategic programmes corresponding to them and applicable in Polish voivodeships were analysed. In a breakdown presented in Table 1 only these methods that were indicated in the analysed documents were taken into account. Dates of their adoption or last updates were also subjected to analysis, in order to take the status of knowledge about the applied methods at the time of their preparation into account.

Table 1.

Research methods and techniques applied during the process of preparation of regional innovation strategies in Poland

\begin{tabular}{|c|c|c|}
\hline Strategy/programme & $\begin{array}{l}\text { Date of } \\
\text { adoption }\end{array}$ & Applied methods and techniques \\
\hline $\begin{array}{l}\text { Regional Innovation } \\
\text { Strategy for the } \\
\text { Dolnośląskie } \\
\text { Voivodeship for } \\
2011-2020\end{array}$ & $\begin{array}{l}30 \text { August } 2011 \\
\text { On } 19 \text { August } \\
2015 \text {, } \\
\text { an attachment } \\
\text { Strategic } \\
\text { Framework } \\
\text { for Smart } \\
\text { Specialisations } \\
\text { of Dolny Śląsk } \\
\text { was prepared }\end{array}$ & $\begin{array}{l}\text { Desk research: forecast of global and national development } \\
\text { trends until } 2020 \text { (trends were listed and described), diagnosis } \\
\text { of the condition of the voivodeship in the following areas: } \\
\text { economic and social potential, regional innovation system. } \\
\text { SWOT analysis }\end{array}$ \\
\hline $\begin{array}{l}\text { Regional Innovation } \\
\text { Strategy for the } \\
\text { Kujawsko-Pomorskie } \\
\text { Voivodeship for 2014- } \\
2020\end{array}$ & $\begin{array}{l}\text { 14 January } \\
2015\end{array}$ & $\begin{array}{l}\text { Desk research: up-date of the region's diagnosis in three areas: } \\
\text { school education and higher-level education; science, including } \\
\text { research and development activities, economy. } \\
\text { SWOT analysis (additional opinions on SWOT factors were } \\
\text { procured from an Internet survey among regional stakeholders) } \\
\text { STEEP analysis } \\
\text { Benchmarking }\end{array}$ \\
\hline $\begin{array}{l}\text { Regional Innovation } \\
\text { Strategy of the Lubelskie } \\
\text { Voivodeship until } 2020\end{array}$ & $\begin{array}{l}31 \text { October } \\
2014\end{array}$ & $\begin{array}{l}\text { Desk research: prospective diagnosis in several areas: } \\
\text { environment; natural resources; population; settlement } \\
\text { network; labour market; level of development and economy } \\
\text { structure; education, science, innovation potential; spatial } \\
\text { management; social and institutional capital; culture; hitherto } \\
\text { use of external funds. } \\
\text { SWOT analysis }\end{array}$ \\
\hline $\begin{array}{l}\text { Innovation Development } \\
\text { Programme of Lubuskie } \\
\text { Voivodeship }\end{array}$ & $\begin{array}{l}\text { Update from } \\
30 \text { August } 2018\end{array}$ & $\begin{array}{l}\text { Desk research: diagnosis of the status of innovation in the } \\
\text { voivodeship } \\
\text { SWOT analysis } \\
\text { Key development factors } \\
\text { Problem tree } \\
\text { Benchmarking } \\
\text { Delphi survey } \\
\text { Telephone interviews }\end{array}$ \\
\hline
\end{tabular}


Cont. table 1.

\begin{tabular}{|c|c|c|}
\hline $\begin{array}{l}\text { Regional Innovation } \\
\text { Strategy for the Łódzkie } \\
\text { Voivodeship: "LORIS } \\
\text { 2030" }\end{array}$ & 26 April 2013 & $\begin{array}{l}\text { Desk research: diagnosis of the innovation potential of the } \\
\text { voivodeship } \\
\text { SWOT analysis in areas: knowledge-based economy; science } \\
\text { in the service of innovative development; knowledge-based } \\
\text { society; regional innovation policy; knowledge-based } \\
\text { administration. } \\
\text { IDI, CATI and CAWI interviews } \\
\text { Region development scenarios }\end{array}$ \\
\hline $\begin{array}{l}\text { Strategic Programme } \\
\text { Regional Innovation } \\
\text { Strategy of the } \\
\text { Małopolskie Voivodeship } \\
2020\end{array}$ & 2 October 2018 & $\begin{array}{l}\text { Desk research: key macro-economic data; modern } \\
\text { technologies; infrastructure of the region's knowledge; R\&D } \\
\text { personnel; instruments of the region's knowledge; } \\
\text { entrepreneurship and promotion of entrepreneurship; } \\
\text { infrastructure for information society; implementation of the } \\
\text { Małopolska development policy in the area of innovative } \\
\text { economy. } \\
\text { Forecast of development trends } \\
\text { Surveys } \\
\text { SWOT analysis }\end{array}$ \\
\hline $\begin{array}{l}\text { Regional Innovation } \\
\text { Strategy for Mazowsze } \\
\text { until } 2020\end{array}$ & 16 March 2015 & $\begin{array}{l}\text { Desk research: profile of operation of cluster initiatives, export } \\
\text { structure, concentration of economic activities } \\
\text { Interviews and surveys } \\
\text { SWOT analysis }\end{array}$ \\
\hline $\begin{array}{l}\text { Regional Innovation } \\
\text { Strategy for the Opolskie } \\
\text { Voivodeship until } 2020\end{array}$ & 1 July 2014 & $\begin{array}{l}\text { Desk research: diagnosis of the innovation potential of the } \\
\text { Opolskie voivodeship, industry analyses } \\
\text { Expert consultations } \\
\text { Prospective studies } \\
\text { PEST analysis } \\
\text { SWOT analysis } \\
\text { Trend forecasting } \\
\text { Delphi method } \\
\text { Creative imaging }\end{array}$ \\
\hline $\begin{array}{l}\text { Regional Innovation } \\
\text { Strategy for the } \\
\text { Podkarpackie } \\
\text { Voivodeship for } 2014 \text { - } \\
2020 \text { for the sake of smart } \\
\text { specialisation (RIS3) }\end{array}$ & $\begin{array}{l}\text { Update of } 28 \\
\text { November } \\
2016\end{array}$ & $\begin{array}{l}\text { Desk research: diagnosis of the innovation potential of the } \\
\text { voivodeship } \\
\text { TOWS/ SWOT analysis, surveys and interviews }\end{array}$ \\
\hline $\begin{array}{l}\text { Entrepreneurship } \\
\text { development plan based } \\
\text { on smart specialisations } \\
\text { of the Podlaskie } \\
\text { Voivodeship for 2015- } \\
2020+\text { (RIS3) }\end{array}$ & 1 March 2016 & $\begin{array}{l}\text { Desk research: diagnosis of the innovation potential of the } \\
\text { voivodeship } \\
\text { Detailed SWOT analysis }\end{array}$ \\
\hline $\begin{array}{l}\text { Regional Strategic } \\
\text { Programme in the area of } \\
\text { economic development } \\
\text { Pomeranian Port of } \\
\text { Creativity }\end{array}$ & $\begin{array}{l}\text { Update of } 10 \\
\text { May } 2018\end{array}$ & $\begin{array}{l}\text { Desk research: conclusions from the analysis of situation in the } \\
\text { area of economic development } \\
\text { SWOT analysis }\end{array}$ \\
\hline $\begin{array}{l}\text { Regional Innovation } \\
\text { Strategy for the Śląskie } \\
\text { Voivodeship for } 2013- \\
2020\end{array}$ & $\begin{array}{l}20 \text { December } \\
2012\end{array}$ & $\begin{array}{l}\text { Desk research: among others pertaining to the results of } \\
\text { foresight projects } \\
\text { Benchmarking } \\
\text { SWOT analysis }\end{array}$ \\
\hline $\begin{array}{l}\text { Research and Innovation } \\
\text { Strategy (RIS3) From } \\
\text { Absorption to Results: } \\
\text { How to Stimulate the } \\
\text { Potential of the } \\
\text { Świętokrzyskie } \\
\text { Voivodeship 2014-2020+ }\end{array}$ & $\begin{array}{l}24 \text { February } \\
2014\end{array}$ & $\begin{array}{l}\text { Desk research: potential of the sector of science and } \\
\text { technology, economic specialisations } \\
\text { Gravitational model } \\
\text { Forecasting } \\
\text { SWOT analysis }\end{array}$ \\
\hline
\end{tabular}


Cont. table 1.

\begin{tabular}{|c|c|c|}
\hline $\begin{array}{l}\text { Regional Innovation } \\
\text { Strategy for the } \\
\text { Warmińsko-Mazurskie } \\
\text { Voivodeship until } 2020\end{array}$ & $\begin{array}{l}28 \text { September } \\
2010\end{array}$ & $\begin{array}{l}\text { Desk research: diagnosis of the social capital and innovation } \\
\text { culture, human capital, innovation needs of companies; } \\
\text { research and development potential of the region; innovation } \\
\text { support system. } \\
\text { SWOT analysis }\end{array}$ \\
\hline $\begin{array}{l}\text { Regional Innovation } \\
\text { Strategy for } \\
\text { Wielkopolska for } \\
2015-2020\end{array}$ & $\begin{array}{l}\text { Update of } \\
30 \text { March } 2015\end{array}$ & $\begin{array}{l}\text { Desk research: analysis of competitiveness and innovation of } \\
\text { the region and enterprises; analysis of management on the } \\
\text { regional and local level; analysis of innovation and } \\
\text { competitiveness of enterprises; analysis of the social sub- } \\
\text { system, analysis of intra-regional diversification and } \\
\text { specialisations. } \\
\text { SWOT analysis } \\
\text { Key success factors } \\
\text { Delphi method } \\
\text { In-depth interviews } \\
\text { Innovation benchmarking }\end{array}$ \\
\hline $\begin{array}{l}\text { Regional Innovation } \\
\text { Strategy for the } \\
\text { Zachodniopomorskie } \\
\text { Voivodeship for } 2011 \text { - } \\
2020\end{array}$ & 22 March 2011 & $\begin{array}{l}\text { Desk research: diagnosis of the socio-economic environment } \\
\text { for innovation development } \\
\text { Competition for smart specialisations of the region } \\
\text { SWOT analysis }\end{array}$ \\
\hline
\end{tabular}

Source: Own work based on the strategies review.

The range of methods and techniques used during the preparation of the regional innovation strategies is diversified. The minimum set of methods includes an analysis of the region's profile with the use of the desk research method encompassing primarily the quantitative data pertaining to various areas of the voivodeship's functioning that are important for innovation development. Due to the requirements set by the European Commission, all regions also applied the SWOT analysis method. A significant percentage of the regions used the benchmarking method (25\%). Analysis of documents also indicates that it was prepared as the SWOT/TOWS method only in the Podkarpackie Voivodeship. The Opolskie Voivodeship and the KujawskoPomorskie Voivodeship also applied the strategic analysis method, PEST (in the KujawskoPomorskie Voivodeship, as the STEEP variant). The Delphi method $(18,7 \%)$ and the scenario and forecast methods were also rarely used. As far as the research techniques are concerned, some voivodeships used interviews and surveys (25\%). An interesting approach was used in the Pomorskie Voivodeship, where a competition was announced in order to select smart specialisations.

\section{Conclusions}

Polish regions fulfilled the ex ante requirement in the form of preparation of regional innovation strategies that make use of the SWOT analysis method, which allowed for full use of the European Union funds. Numerous voivodeships used a broader range of research methods and techniques, but the analysis of prepared documents does not always deliver full 
information whether the qualitative methods were commonly applied. However, attention should be drawn to the fact that in the majority of them, regional foresight type projects with extended time horizon were implemented previously, where such methods and techniques were commonly used.

Literature pertaining to best practice in the area of preparation of regional innovation strategies indicates forecasting activities and diagnostic tools which are aimed at determining potential synergies that appear in the analysis of the regional context. Proper assessment of the potential in the area of regional specialisations requires use of diverse qualitative and quantitative data, pertaining primarily to scientific and technical indices, sectoral distribution of employment in the region, indices pertaining to export, road maps or forecasting methods. A certain obstacle with respect to the study of the regional potential was lack of preparation of the public statistics for the aggregation of significant data on the level of the region or lower. The quantitative approach is also mainly aimed at past and current specialisations of the region and limits the possibility of inter-sectoral and inter-technological dimension to indicate new types of activities (Griniece, and Panori, 2017). The information gap resulting from the insufficient quantitative data may be supplemented by the applied qualitative methods that use knowledge and also expert intuition.

Another important finding was also the fact that the Polish regions were not only striving to fulfil the ex ante requirements, but many of them used the foresight type project results implemented earlier, or applied the research methods and techniques typical for them, such as, e.g., the Delphi method, during the preparation of the regional innovation strategies.

\section{References}

1. Bowonder, B., Dambal, A., Kumar, S., and Shirodkar, A. (2010). Innovation Strategies for Creating Competitive Advantage. Journal Research-Technology Management, Vol. 53, Iss. 3, pp. 19-32.

2. Brożyk, P. (2006). Globalizacja: istota, szanse, zagrożenia. Res Humana, nr 5, pp. 16-20.

3. Capello, R., and Kroll, H. (2016). From theory to practice in smart specialization strategy: emerging limits and possible future trajectories. European Planning Studies, No. 24(8), pp. 1393-1406.

4. Clark, J., Guy, K. (1998). Innovation and Competitiveness: A Review. Technology Analysis and Strategic Management, Vol. 10(3), pp. 363-395.

5. Conway, S., Steward, F. (2009). Managing and shaping innovation. Oxford: University Press. 
6. de Jong, J.P.J. (2011). Perceived competition and innovative intentions in Dutch small and medium enterprises. International Journal of Innovation Management, Vol. 15(4), pp. 687-707.

7. Facts: the benefits of economic globalisation in Europe, https://www.europarl.europa.eu/ news/en/headlines/economy/20190603STO53520/facts-the-benefits-of-economicglobalisation-in-europe, 23.09.2020.

8. Fellnhofer, K. (2017). Evidence revisited: Literature on smart specialisation calls for more mixed research designs. International Journal of Knowledge-Based Development, No. 8(3), pp. 229-248.

9. Foray, D., and Goenega, X. (2013). The goals of smart specialization. S3 Policy Brief Series, No. 01/2013 Luxembourg: Publications Office of the European Union.

10. Foray, D., David, PA, and Hall, B. (2009). Smart Specialization - The Concept. Knowledge Economists Policy Brief no. 9, http://ec.europa.eu/invest-in-research/pdf/download_en/ kfg_policy_brief_no9.pdf?11111, 18.08.2020.

11. Griniece, E., Panori, A., Kakderi, C., Komninos, A., Reid, A. (2017). Methodologies for Smart Specialisation Strategies: A view across the EU regions. International Conference for Entrepreneurship, Innovation, and Regional Development (ICEIRD 2017), UniversityIndustry Links: Coproducing Knowledge, Innovation \& Growth, Conference Proceedings, pp. 321-330.

12. Grzybowska, A. (2013), Globalizacja - szanse i zagrożenia, współczesne problemy ekonomiczne. In: G. Wolska (Ed.), Polityka państwa a proces globalizacji. Studia Ekonomiczne, Zeszyty Naukowe Wydziałowe Uniwersytetu Ekonomicznego w Katowicach.

13. Herodowicz, T. (2018). Gospodarczy wymiar globalizacji. Rozwój Regionalny i Polityka Regionalna, $n r$ 41, pp. 13-30.

14. Jacoby, W., Meunier, S. (2010). Europe and the Management of Globalization. Journal of European Public Policy, Vol. 17, Iss. 3, pp. 299-317.

15. Kołodko, G.W. (2007). Polska z globalizacja w tle. Instytucjonalne i polityczne aspekty rozwoju gospodarczego. Toruń: Towarzystwo Naukowe Organizacji i Kierownictwa „Dom Organizatora".

16. Lundvall, B.Å. (2007). National Innovation Systems-Analytical Concept and Development Tool. Journal Industry and Innovation, Vol. 14, Iss. 1, pp. 95-119.

17. Matusiak, K.B. (Ed.) (2005). Innowacje i transfer technologii. Słownik pojęć. Warszawa: Polska Agencja Rozwoju Przedsiębiorczości.

18. Moen, Ø., Tvedten, T., and Wold, A. (2019). Exploring the relationship between competition and innovation in Norwegian SMEs. Journal Cogent Business \& Management, Vol. 5, Iss. 1, pp. 1-15. 
19. Nogalski, B., Karpacz, J. (2012). Zdolność technologiczna jako źródło przewagi konkurencyjnej firm produkcyjnych. Studia Ekonomiczne Regionu Łódzkiego, wyd. specjalne, pp. 173-186.

20. Regulation (EU) No 1303/2013 of the European Parliament and of the Council of 17 December 2013.

21. Siqueira, A.C., Cosh, A.D. (2008). Effects of product innovation and organizational capabilities on competitive advantage: evidence from UK small and medium manaufacturing enterprises. International Journal of Innovation Management, Vol. 12(2), pp. 113-137.

22. Stabryła, A. (Ed.), (2009). Doskonalenie struktur organizacyjnych przedsiębiorstw w gospodarce opartej na wiedzy. Warszawa: Wydawnictwo C.H. Beck.

23. Surugiu, M.R., Surugiu, C. (2015). Interdependence between European Countries: Implications for Businesses and Marketing Framework. Procedia Economics and Finance, No. 32, pp. 131-138.

24. Third report on economic and social cohesion (COM(2004) 107 final).

25. Weresa, M. (2012). Systemy innowacyjne a konkurencyjność w świetle wybranych koncepcji teoretycznych. Prace i materiały Instytutu Gospodarki Światowej SGH, nr 311. Warszawa: SGH. 